\title{
The Lawyer Who Haunts Us: Yin Zhaoshi and the Bright Day
}

\author{
by Alison W. CONneR*
}

\section{INTRODUCTION}

Lawyers and courtrooms feature in many American movies, but in Chinese films, especially the early ones, lawyers are much harder to find. Despite the relative newness of a modern legal profession, however, lawyers do make a few revealing, if essentially cameo, appearances in pre-1949 Chinese films. But it is only in Bright Day (Yanyang Tian 1948) that a lawyer is given the central, most important part, and his eloquent arguments to a packed courtroom mark the high point of the film. Bright Day may be less famous now than other 1940s Chinese movies, but for this and other reasons it remains an important work that deserves much closer attention. The movie was produced by Wenhua Film, a company known for its high standards, it was written and directed by Cao Yu, China's most important modern playwright, and its cast included some of Shanghai's biggest stars. Bright Day was also filmed at a critical juncture in history, when two very different visions of justice-or injusticecompeted for Chinese hearts and minds.

Bright Day is clearly a product of its time and place, and it shares the bleak mood one finds in many other movies of the immediate postwar era. ${ }^{1}$ Thus much of the film depicts the oppressive behavior

* Professor of Law, the William S. Richardson School of Law, University of Hawai` at Mānoa. Research for this article was conducted with the assistance of a grant from the William S. Richardson School of Law, which is gratefully acknowledged. I would also like to thank Paul Fonoroff for bringing the movie to my attention; Diane Frake, Amy Paulus and Cheong-Ming Wai for helping me get a copy of the film to watch; Tao Lifeng for research assistance; and Avi Soifer and Jerome A. Cohen for their comments and suggestions on an earlier version of this article.

${ }^{1}$ See Paul G. Pickowicz, Victory as Defeat: Postwar Visualizations of China's War of Resistance, in Becoming Chinese: Passages to Modernity and Beyond 365 (Wen-hsin Yeh ed., 2000). 
of profiteers who enriched themselves during the Japanese occupation and the thugs they employ to terrorize anyone who, like its lawyer-hero Yin Zhaoshi, stands in their way. But the movie also illustrates the power of an individual lawyer to defeat those threatening forces: Yin believes in the law and he is vindicated in court. Thus, in contrast to its ominous opening, the movie ends in brilliant sunlight, on a positive, high note. Of course, Bright Day is not a documentary (and even documentaries reflect points of view), and its screenwriter-director had no special knowledge of law. The movie's trial and Yin's role in it were ripped from the headlines and echoed popular literature of that time, reflecting current events when the movie was made. Yet the film nevertheless raises universal themes of justice that even now offer us much food for thought.

This article analyzes Bright Day's depiction of a lawyer and his courtroom trial and, more broadly, the ideas of justice that both reflect. Part II introduces Bright Day in its historical and artistic context and discusses the film's critical reception. Part III analyzes the plot of the movie, and Parts IV and V discuss the character of Yin Zhaoshi and the special role he plays in the trial. Part VI discusses varying interpretations of Bright Day's message and considers the film's contribution as well as its possible relevance to the modern Chinese legal profession. Though Bright Day was made more than sixty years ago, it raises surprisingly contemporary issues about the role of lawyers in China, and its visions of justice may still resonate today. ${ }^{2}$

\footnotetext{
${ }^{2}$ At a talk I gave a few years ago about Bright Day, a Chinese student suggested that it would be better for me to analyze the 1959 film Storm (Fengbao) because it is about a "real historical figure" and "a great lawyer." Storm does feature the lawyer and labor organizer Shi Yang (1889-1923) as one of its central characters and the action is set in the 1920s, also during the Republican period. But that movie was filmed after the 1949 revolution and it is based on Jin Shan's 1958 revolutionary play Hongse Fengbao (Red Storm), which should really be viewed as a "worker play." See Xiaomel Chen, Acting the Right Part. Political Theater and Popular Drama in Contemporary China 11 (2002). Storm may be interesting for a number of reasons, but not because it is about a lawyer or the legal system-and Storm is arguably more dated than Bright Day.
} 


\section{BRIGHT DAY: THE MOVIE AND ITS CONTEXT}

\section{A. Chinese Movies of the Late 1940 s}

Bright Day ${ }^{3}$ was filmed after the end of the Second Sino-Japanese War but before the establishment of the People's Republic of China. Movies of that brief era (1946-49), when China was torn by civil war between the Nationalist Government and the Communist Party, were part of a second "golden age" of Chinese filmmaking, ${ }^{4}$ and the best of them are highly engaging even now. Though virtually all of them were shot in black and white, 1940s movies are technically better than the earlier films, a result of the use of sound sets and the greater attention paid to lighting and camera work. The narrative tempo is faster than in Chinese movies of the 1920s and 1930s, and the acting (always important in Chinese film) looks more natural, at least to the contemporary eye. As some critics have noted, moreover, movies from this era are harder to categorize as "leftist" or otherwise, which resulted in more interesting and complex stories than those in most films of the 1930s. ${ }^{5}$

Whatever their artistic merit as the creative expressions of their writers, directors and actors, Chinese films of the late 1940s are of particular interest for the light they shed on the political and social concerns of the day. This brief period followed eight years of devastating war, in which many millions of people died, and the brutal

${ }^{3}$ Yanyang Tian (Bright Day or Bright Sunny Day). Cao's screenplay was published in 1948, the year the film was released. YanYang TIAN (Wenhua Shenghuo Chubanshe, 1948). It was also published in CAO Yu QUaNı [Complete Works of Cao Yu], 1948. The screenplay appears in some but not all later collections of Cao's complete works, including CAO YU QUANJ [Complete Works of Cao Yu] vol. 7 (Tian Benxiang and Liu Yijun, eds., 1996). Although many other 1940s Chinese movies are readily available on DVD in China, this film apparently isn't one of them. The 1973 movie also titled Bright Day (Yanyang Tian) has no relationship to the Cao Yu film discussed in this article; it was made during the Cultural Revolution and has an entirely different plot.

${ }^{4}$ Yingin Zhang, Chinese National Cinema 55 (2004). Leo Ou-fan Lee, The Urban Milieu of Shanghai Cinema, 1930-1940: Some Explorations of Film Audience, Film Culture, and Narrative Conventions, in CINEMA AND URBAN CULTURE IN SHANGHAI, 19221943, at 86 (Yingjin Zhang ed., 1999). The pre-war movies of the 1930s, especially those made during 1931-1937 (before the Sino-Japanese War), constituted a "first golden age" of Chinese cinema.

${ }^{5}$ See Paul G. Pickowicz, supra note 1 , at $390 \mathrm{ff}$. 
occupation of much of China, ${ }^{6}$ including the Shanghai region, where this film was made. Although the Nationalist Government returned to occupied China after Japan's defeat, it was soon engaged in a bitter struggle with the Communists, both on and off the battlefield. Many of these movies depicted harsh social conditions and criticized the corruption and injustice of postwar Chinese society, whatever their frame of reference or political point of view, or they reflected the depression and hopelessness of a people worn out by the long years of war against the Japanese. ${ }^{8}$ Such films contained very tough social and political criticism, whether because their views and concerns were widely shared even within the Nationalist Party or under pressure from society and the film world. ${ }^{9}$ Bright Day, like other late 1940 s movies, was written at a time of soaring prices and inflation, widespread corruption, labor unrest and student protests, especially in cities like Shanghai-and it was released in theaters barely a year before Shanghai fell to the Red Army in May $1949 .^{10}$

\section{B. Wenhua Film Company (1946-1952)}

Bright Day was produced by the Wenhua Film Company (Wenhua Yingye Gongsi), one of two privately owned film studios operating in Shanghai after the end of the Sino-Japanese War. Founded in 1946 by Wu Xingzai, a businessman with a strong interest in movies, the company began operations in early $1947 .{ }^{11}$ During its brief life, Wenhua was known for its high level of artistry and its films represented the "humanistic tradition of Chinese film-making at its

${ }^{6}$ Rana Mitter, China's War With Japan 1937-1945: The Struggle For Survival 5-6 (2013). Diana Lary, The Chinese People at War: Human Suffering and Social Transformation, 1937-1945 1- 8, 173-78.

7 Jubin Hu, Projecting a nation: Chinese national Cinema Before 1949 167-168 (2003).

${ }^{8}$ Pickowicz, supra note 1 , at $390 \mathrm{ff}$.

$9 / d$., at 395. HU, supra note 7, at 166

${ }^{10}$ Suzanne Pepper, Civil War in China: The Political Struggle 1945-1949, 66, 95, 111 , 147 ff. (1999); Odd Arne Westad, Decisive Encounters: The Chinese Civil War 1946-50, 72-75, 91 (2003). Bright Day opened on May 21, 1948 and the Communist army entered Shanghai on May 25, 1949.

${ }^{11}$ Zhongguo Dianyingshi Gangyao [Compendium on the History of Chinese Film] 104 (Yu Ji et al., eds., 2007). 
best."12 Many leading creative talents of that period were associated with Wenhua, including the directors Fei $\mathrm{Mu}$, Sang $\mathrm{Hu}$ and Huang Zuolin (Zuolin), writer Eileen Chang and actor-director Shi Hui. ${ }^{13}$ Wenhua's most famous movie is probably Fei Mu's masterpiece, Spring in a Small Town (Xiaochen zhi Chun 1948), but the studio also produced films like Huang Zuolin's Night Inn (Ye Dian 1947), an adaptation of Maxim Gorky's play The Lower Depths. Wenhua was known for its sophisticated comedy-dramas that appealed to an urban audience, such as Long Live the Missus (Taitai Wansui 1947), a Sang Hu-Eileen Chang collaboration, and Sorrows and Joys of Middle Age (Aile Zhongnian 1949), which Sang Hu directed.

Wenhua productions are often contrasted with those of its rival, Kunlun Film Company (Kunlun Yingye Gongsi), ${ }^{14}$ the other private film studio in postwar Shanghai, which was associated with more "leftist" or "socialist" fare, especially films made by Shen Fu and Zheng Junli. ${ }^{15}$ Kunlun produced well-made political melodramas such as Myriad Twinkling Lights (Wanjia Denghuo 1948), Hope in the World (Xiwang zai Renjian 1949), ${ }^{16}$ and Crows and Sparrows (Wuya yu Maque 1949), ${ }^{17}$ which contain some of the sharpest political commentary on the social ills of that time. Kunlun filmed the big blockbusters of the late 1940s, most notably Spring River Flows East, (Yi Jiang Chunshui Xiang Dong Liu), ${ }^{18}$ sometimes called China's Gone with the Wind, and 8000 Li of Cloud and Moon (Baqian Lilu Yun he Yue), ${ }^{19}$ both released in 1947 and made on a much grander scale than Wenhua productions, including Bright Day.

${ }^{12}$ Zhiwei Xiao, Chinese Cinema, in ENCYCLOPEDIA OF CHINESE FILM, 3-30, 20 (Yingjin Zhang ed., 1998). See also Yu JIZHU, ZHONGgUo Dianying SHI [History of Chinese Film] 105-113 (2011).

${ }^{13}$ The directors Huang Zuolin and Sang Hu were mainly responsible for the creative side of Wenhua. ZnONGgUo DianYINGSHI GANGYAO, supra note 11, at 107.

${ }^{14}$ For Kunlun studio and its films, see LU JIZHU, ZHONGGUO DIANYING SHI [History of Chinese Movies] 97-105 (2011).

${ }^{15}$ According to this source, the humanistic movies (renwen dianying) portrayed human lives and human relationships rather than focusing on the reality of the times. ERSHI SHII ZHONGgUo WenYI TUWEN ZHI: DIANYING JUAN [Illustrated Essays on the Arts in Twentieth-Century China: Movies] 82 (Xu Naixiang, ed., 2002).

${ }^{16}$ Both directed by Shen Fu.

${ }^{17}$ Directed by Zheng Junli and actually completed after the 1949 Communist victory.

${ }^{18}$ Directed by Cai Chusheng and Zheng Junli.

${ }^{19}$ Directed by Shi Dongshan. 


\section{Writer-Director Cao Yu}

Bright Day was written and directed by Cao Yu (Wan Jiabao, 19101996), China's foremost twentieth-century playwright, and it is the only screenplay he wrote. Although Cao Yu's prestige may have reached its height in the early $1960 \mathrm{~s},{ }^{20}$ his plays continue to be staged and the centennial of his birth was marked in China with special performances of his major plays. ${ }^{21}$ Cao's best-known works include the trilogy Thunderstorm (Lei Yu 1934), Sunrise (Richu 1936) and The Wilderness (Yuanye 1937), which were enthusiastically received by audiences in the 1930s. Thunderstorm, which Cao wrote as a student in 1933 and which was published the following year, is the most famous dramatic work of the pre-war period, and possibly the most performed modern Chinese play; it is as famous as a written script as it is in performance. ${ }^{22}$ During the Sino-Japanese war, Cao wrote Metamorphosis (Tuibian 1940) and Peking Man (Beijing Ren 1940), which is usually considered his finest play. Even critics who are not enthusiastic about Cao Yu's plays view him as the key figure in introducing and establishing a modern Chinese theater with spoken dialogue (huaju), as opposed to traditional theater or opera (xiju), which is sung. ${ }^{23}$

Cao Yu spent most of the war years in Chongqing, followed by a year-long lecture tour in the United States at the invitation of the State Department. But in early 1947 he returned to China and accepted a teaching position at a Chinese opera institute in Shanghai. Cao was deeply interested in film and his friend, the director Huang

\footnotetext{
${ }^{20}$ Bonnie S. McDougall and Kam.Louie, The literature of China in the Twentieth CenTURY 306 (1997).

${ }^{21}$ See for example Beijing Review. http://www.bjreview.com.cn/quotes/txt/ 2010-10/25/content 368810.htm. http://english.cntv.cn/program/cultureexpress/ 20100906/101224.shtml.

22 Bonnie S. MCDougall and Kam Louie, supra note 20, at 177-181, 305-307.

${ }^{23}$ C.T. Hsia, A History of Modern Chinese Fiction 317-18 (3rd ed. 1999). Not a fan of Cao Yu, he describes the first three plays as "essentially on the order of the wellmade melodrama" and described Cao himself as "a conscientious playwright very much at the mercy of the prevalent attitudes of his time." Overall, his plays "vaunt a superficial leftist point of view." (Fans of Ibsen and O'Neill will feel at home with Cao Yu's oeuvre.) Edward Gunn, Shanghai's "Orphan Island" and the Development of Modern Drama, in Popular Chinese Literature and Performing Arts in the People's RePublic of China 1949-1979, 36, 38-40 (Bonnie S. McDougall, ed., 1984).
} 
Zuolin, introduced him to Wenhua Film and invited him to direct a movie. ${ }^{24}$ The plays in the Sunrise trilogy had all been made into movies by other directors, but this was the first time that Cao had written a screenplay or directed a movie himself, and the crew praised him for his meticulous preparation and careful filming. ${ }^{25}$ Cao spent six months on the screenplay, from April to November 1947, and after a month of preparation he started shooting the movie on December 31,1947 , with Huang Shaofen, one of the best directors of photography in China, as his cinematographer. ${ }^{26}$ After five months of shooting followed by a month spent editing, Cao Yu completed his work on the film and Bright Day opened in Shanghai in May 1948. ${ }^{27}$ The appearance of any new work by Cao Yu, including a film, was a major event, and not surprisingly Cao's name figures prominently in the Shanghai newspaper advertisements for Bright Day.

\section{Movie Stars Shi Hui and Li Lihua}

In addition to its famous director, Bright Day starred some of Wenhua Film's best actors, including the great Shi Hui (Shi Yutao 1915-1957) as its lawyer-hero Yin Zhaoshi. ${ }^{28}$ Shi was known as "King of the Stage" in wartime Shanghai, ${ }^{29}$ where he had acted in several of Cao Yu's plays, including both Thunderstorm and Sunrise..$^{30} \mathrm{~A}$ brilliant and highly versatile actor, with a distinctive beaky nose and a different hairstyle for every part he played, Shi Hui appeared in

${ }^{24}$ ZHONGgUO DIANYINGSHI GaNGYaO, supra note 11 , at 107.

$25 / d$.

${ }^{26}$ EnCYCLOPEDIA OF CHINESE FILM 194-195 (Yingjin Zhao and Zhiwei Xiao, eds., 1998) on Huang Shaofen (Huang Ke). A complete list of the cast and crew of Bright Day, along with the plot summary, is given in Yanyang Tian in ZHONGGUO DIANPIAN DADIAN 1931-1949.9 [Encyclopedia of Chinese Films] 447-48 (China Film Arts Research Center and China Film Archives, eds., 2005).

${ }^{27}$ Ding YePING, Zhongguo Dianying Yishu 1945-1949, 241 (1998).

${ }^{28}$ In Phony Phoenixes (Jiafeng Xuhuang 1946), Long Live the Missus (Taitai Wansui 1947), Night Inn (Ye Dian 1947), Sorrows and Joys of Middle Age (Aile Zhongnian 1949), for example. On the Wenhua Film Conpany, see Paola lovene, Phony Phoenixes: Comedy, Protest, and Marginality in Postwar Shanghai, in CHINA ON THE MARGINS $267 \mathrm{ff}$. (Sherman Cochran and Paul G. Pickowicz, eds., 2010).

${ }^{29}$ Paul G. Pickowicz, Acting Like Revolutionaries: Shi Hui, the Wenhua Studio, and Private-Sector Film-making, 1949-52, in DILemmas of VICTORY: THE EARLY Years of the People's Republic of China 25-58 (Jeremy Brown and Paul G. Pickowicz, eds., 2007).

${ }^{30} / d$. at 58-59. 
some of the best movies of the late 1940s, including Wenhua's Long Live the Missus and Joys and Sorrows of Middle Age. Shi excelled in comic as well as dramatic roles, and his performance in Bright Day brought humor as well as humanity to the role of Lawyer Yin, whose character might otherwise have seemed self-righteous or simply too good to be true. In his other movies, Shi Hui played a range of very different characters, from the truly repellant innkeeper of Night Inn to the appealing widower in Sorrows and Joys of Middle Age who finds love late in life despite the disapproval of his unfilial sons. In 1950 Shi, who had remained in China after 1949, directed and starred in This Life of Mine (Wo Zhe Yibeizi), in which he gave a tourde-force performance as a Beijing policeman from his youth in the last days of the Qing dynasty to old age in 1949.

Shi Hui's co-star in Bright Day was the glamorous Li Lihua (b. 1924), a popular actress who was well known in Hong Kong as well as Shanghai. Although Shi's Lawyer Yin is without a doubt the most important character in the film, ${ }^{31} \mathrm{Li}$ actually got top billing in the movie credits as well as all the newspaper publicity. ${ }^{32}$ The two actors had already starred together in Phony Phoenixes (Jiafeng Xuhuang), ${ }^{33}$ another Wenhua production-though in Bright Day Li plays not Shi's love interest but his niece. Phony Phoenixes caused a stir when the Shanghai Barbers Association disrupted its preview, and perhaps partly for that reason the movie was a huge box office success when it was released in $1947 .{ }^{34}$ But Phoenixes is also an en-

\footnotetext{
${ }^{31}$ Yin Zhaoshi is recognized as the central, most important character in all discussions of the movie that I have seen. For example, in ZHANG YAOIIE, XIJU DASHI: CAO Yu [Great Masters of Theater: Cao Yu] 278-79 (2002).

${ }^{32}$ In every version of the movie advertisements in the Shanghai newspaper SHEN$B A O$ [Shanghai News], as well as in the screen credits. (Li Lihua also received top billing for Phony Phoenixes.) Unlike her co-star Shi Hui, who remained in Shanghai after 1949, Li went on to a long and successful career in Hong Kong, where she starred in many Shaw Brothers movies before her retirement in the 1970s. BIOGRAphical Dictionary of Chinese Women: The Twentieth Century 1912-2000 309 (Lily Xiao Hong Lee and A.D. Stefanowska, eds., 2002 ). For a list of Li's films, see lilihua.net/ Filmtitles.htm.

${ }^{33}$ Directed by Huang Zuolin. The film's title is sometimes translated as Fake Bride, Phony Bridegroom.

${ }^{34}$ For more on Phony Phoenixes and the barbers' protest, see Zhiwei Xiao, Social Activism during the Republican Period: Two Case Studies of Popular Protests against the Movies, Twentieth-Century ChInA, vol. XXV, no. 2 (April 2000) 55-74; and Paola lovene, supra note 26.
} 
tertaining romantic comedy with serious undertones, and both $\mathrm{Li}$ and Shi (this time with marcelled hair) give very engaging performances. Moreover, although Shi Hui often played older roles or aged many years during the course of a film,,$^{35}$ in 1948 he was still young and handsome, and Bright Day's audiences might easily picture Li and Shi as the comic romantic duo of Phoenixes only a year or so earlier. Indeed, many of the newspaper advertisements for Bright Day show Li Lihua and Shi Hui together, even walking hand in hand, as if they were still a couple. ${ }^{36}$

As the major stars of Bright Day, Shi Hui and Li Lihua were supported by a very able ensemble cast, most of whom had appeared with Shi in Long Live the Missus and Phony Phoenixes or had starred together in other Wenhua films. The movie's cast included Han Fei (as Ma Biqing), Yin Zheng (as Mrs. Yin), and Cui Chaoming (as Yang Da). Although some of them received more publicity than others in the daily newspaper advertisements, they were all talented actors, well known to Shanghai movie and theater audiences of the day.

\section{E. Bright Day in Theaters}

Bright Day opened in five major Shanghai theaters, including the Carlton as "Lawyer Yin Says No," on May 21, 1948, and it played in at least one or two Shanghai theaters throughout June. ${ }^{37}$ On its release, the film was praised for its acting and production, as well as for Cao's creation of a flesh-and-blood character in its hero, and in general the movie "resonated strongly with China's cultural and artistic world." ${ }^{38}$ Bright Day received critical praise as a work that

${ }^{35}$ In Long Live the Missus and Night Inn, Shi Hui plays an old man, and in This Life of Mine and Sorrows and Joys of Middle Age he ages during the course of the movie.

${ }^{36}$ For example, in the large SHENBAO movie ad of May 27, 1948. Of course the film itself does not suggest an incestuous relationship; she is simply a partner in Yin's professional activities.

${ }^{37}$ SHENBAO [Shanghai News] throughout May and June 1948; movie ads began appearing on May 7, before the movie actually opened. The film played at the Empress, Ritz and Golden Gate as well as the Carlton Theater. The English publicity for Bright Day describes it as "A Chinese Picture Written \& Directed by Tsao Yu," and it is the only Chinese film advertised in the English-language North China Herald that day (May 21, 1948). Bright Day also played in theaters in Nanjing and other major Chinese cities beginning in May. CHen SUYUN, CAO YU XIJU YU ZhengzHI [Cao Yu's Plays and Politics] 293 (Taipei: Wenshizhe Chubanshe 2007).

${ }^{38}$ ERSHI SHII ZHONGgUO WENYITU WENZHI, supra note 15. 
shared many characteristics of Cao Yu's stage creations. Although some reviewers had doubts about the political message of the movie, most noted Cao Yu's high level of artistic skill, reflected in the film's dramatic plot, tight structure, clearly delineated characters, succinct dialogue, and rich literary quality and atmosphereall very impressive achievements in a first film. ${ }^{39}$ The novelist Ba Jin, for example, expressed admiration for the quality of Cao Yu's screenplay: "He relies not on romance, a complicated plot, a frightening or investigative story, or deceptive tricks, but on an intense feeling of righteousness and a clean, neat technique; he captures our hearts and makes us feel Yin's life, worry, anger, joy and happiness." ${ }^{40}$

\section{THE PLOT OF BRIGHT DAY}

Bright Day's plot ${ }^{41}$ is direct and straightforward, very different in character from Cao Yu's plays, though like them it attacks corruption, social inequalities and injustice. The film's story is told in nine acts, and the plot, with its intriguing legal content, is worth recounting in some detail.

\section{A. We Meet the Villains (and the Hero)}

The action takes place in an unnamed city, although the movie is obviously set in Shanghai, where it was filmed, and it begins in the fall. After an ominous opening scene in which an apparently empty pedicab rolls slowly down a darkened street, ${ }^{42}$ we meet the villains

${ }^{39}$ Zhongguo Dianying Fazhanshi [History of the Development of Chinese Cinema] vol. 2265 (Cheng Jihua, ed., 2d ed. 1980). The first edition was prepared in 1963.

${ }^{40}$ CaO Yu YanIIU ZILIAO [Research Materials on Cao Yu] 1198 (Tian Benxiang, Hu Shuhe, eds., 1991).

${ }^{41}$ In earlier discussions of the plot, I relied on the screenplay and contemporary reviews, which is of course a very risky practice. In This Life of Mine, for instance, Shi Hui changed the movie's ending during filming, and consequently discussions that rely on the original screenplay or reports about the film get the ending wrong. In fact, Bright Day follows the screenplay closely, despite some minor changes. But of course a film is much more than its screenplay or story: you really have to see it.

${ }^{42}$ The avant-garde filmmaker and historian Jan Leyda praised this opening scene, although he also suggested that openings are not necessarily followed by an equally good story. JAN LEYDA, DIANYING: AN ACCOUNT OF FILMS AND THE FILM AUdIENCE IN CHINA 170 (1972). 
of the piece, chief among them Jin Huanwu. Mr. Jin (lit., "gold"), a rich merchant who used his position in the collaborationist government to hoard goods and profiteer, wears a silk robe and lives in the greatest of comfort. As he sits plotting with his two henchmen, Yang Da and Ma Biqing, the camera slowly pans over his wellappointed living room with all its luxury: a fire is burning in the fireplace, a radio is playing, the sofas are deep. This brief act creates a dark atmosphere and sets the plot in motion as the villains discuss their plans; it is through their conversation that we are introduced to Yin Zhaoshi. Jin needs a secure place to store his goods and they have decided the orphanage property owned by Yin's friend Wei Zhuoping would be ideal. Jin instructs Yang and Ma to get the property at all costs: Wei must be forced to sell. Ma says it's just that the lawyer Yin makes trouble, always involving himself in matters that don't concern him. "That man named Yin?" Jin asks. "He's a lawyer," says Ma. "The lawyer who interferes with my business?" "That's the one." ${ }^{.43}$

In the next sequence, we meet Yin Zhaoshi and his family. When we first see Yin, he is practicing tai chi in his yard, wearing shabby old clothes, his usual at-home attire a mismatched jacket and trousers, his hair uncombed. Children are playing at the orphanage next door and his special favorite little Qiao Qiao visits with him over the fence. Then his niece Yin Jinxiu, a newspaper reporter and Yin's partner in many activities, joins him, and she too visits with Qiao Qiao. We are next introduced to Director Wei Zhuoping of the orphanage, who is a close friend as well as neighbor to the Yins. Finally Mrs. Yin appears at the window to call them all in to dinnerin a house with furnishings as plain as Jin's were luxurious.

\section{B. The Plot Thickens}

Wei tells his friend that Jin has made an excellent offer to buy the orphanage land and he doesn't know what to do. Yin advises him not to sell if he doesn't wish to do so, and even raises the matter

${ }^{43}$ A plot summary of Bright Day can be found in ZHONGgUO SISHI NIANDAI DIANYING GusH [Stories from Chinese Movies of the 1940s] (Shao Zhou, ed., 1992), although this account leaves out key scenes. No summary can cover everything, but this one omits the first scene entirely, which means it doesn't properly introduce the villains, and through them, the hero of the movie. It also omits the essential last act. 
with Jin's two henchmen. But Yang and Ma increase the pressure on Wei, threatening to reveal that he had served as head of a baojia for a few days under the Japanese occupation-and is therefore as good as a traitor. Wei is frightened and gives in to their blackmail; as the two thugs stand over him, he reluctantly signs the contract of sale-without revealing to his friend Yin the reason he has decided to sell. The orphanage is packed up, and Yin, his wife, and their niece sadly wave goodbye as Wei and the orphans all drive away. When Jinxiu goes away herself for three months, the Yins are left alone without any "family" and with no word from Wei. One evening, Yin and his wife suddenly remember that it is his fortieth birthday, but at the same time they sadly realize that there is no one to call on them, not even Wei, to congratulate Yin and wish him well. Suddenly Yin Jinxiu and her friend Dr. Zhou arrive to celebrate with them and Yin's glum mood lifts-though he is about to learn some startling facts.

Shortly after Jinxiu's return home, she goes in search of Wei and the new location of his orphanage, but she is horrified to discover the orphans living in wretched quarters. After only a few weeks in the comfortable new house they were promised, she learns, the villains forced them out, and Wei and the orphans ended up in increasingly miserable housing. The children are sick, including the Yins' favorite, little Qiao Qiao, and Wei himself is ill but too ashamed to seek help from his friends. Jinxiu urges Yin to act immediately, and the two of them rush off to Jin's house, where Yin confronts Jin's henchmen and is beaten up by them. Yin and his niece return home only to find that Jin's gang has broken into their house and destroyed everything they could, smashing windows and furniture alike. When Jinxiu sees Mrs. Yin standing in the midst of the wreckage, she wonders what kind of world could let such things happen. "We've been good people, we've always tried to help others and we've endured many hardships. But now good people simply have no power. It's shameful, shameful!" Yin's reply is typical of his views: "It's shameful that good people are oppressed, it's shameful that good people are oppressed again and again but don't feel their oppression. No, that's not right, it's good people like us who don't rise up to fight evil, to struggle to the death with those bastards. That's the disgrace!"

When a shamefaced Wei finally comes to see the Yins, he explains what has happened, and tells them he was bullied into giving up the 
orphanage land, and he was too sick to call on Yin for his birthday. Jin and the others are collaborators who profiteered during the war, he tells them. "Traitors!" exclaims Yin, who is shocked but galvanized into action. He immediately drops his fee-paying work and directs all his energies towards investigating Jin's crimes, interviewing those who were affected and drafting the complaint he will file against Jin. As Yin sits at his desk in the freezing house (the windows have not been repaired), Mrs. Yin and Jinxiu hover over him and hand him cups of tea; they too are bundled up in coats and scarves. Yin names his friend Wei as the chief witness and files his complaint with the court as the plaintiff (yuangao). Yin's efforts are rewarded: $\mathrm{Ma}$ and Yang are arrested, and even Mr. Jin, exiting from a fancy car and still wearing his silk robe, is led away by the police.

\section{C. "We Win A Lawsuit!"}

The last two acts of Bright Day are of special interest. The night before the first court session, Dr. Zhou arrives to show Jinxiu the detailed news reports in the evening paper describing the arrests and the upcoming trial. "Yes, I wrote it!," Jinxiu tells him. All the major newspapers carry reports of Jin's arrest-along with Yin Zhaoshi's name. "This is your great victory," Zhou tells Yin and congratulates him.

Then a frightened Director Wei pays a surprise visit to speak with Yin. "Did you file the complaint, did you name me as a witness? I received a summons from the court." When Yin nods, Wei says "1 told you not to make this public. I'm so sorry but I really can't be a witness in the case. I think it's better if you don't go to court either." Wei then shows Yin what he has received from the villains: a threatening letter and a loaded gun. "They are preparing to attack me, don't let them know you've seen me." When Wei prepares to return home, he discovers that the Yins' house is surrounded by Jin's thugs, who can be seen lurking in the darkness outside, and he has to remain there for the night. But Wei is still afraid to go to court, and Yin presses him for the reason, "I ask you, what have you done, what have you done?" Shamefaced, Wei finally admits that he was a "collaborator" because he briefly served, under duress, as a leader (baozhang) in a baojia community-based neighborhood organi- 
zation. ${ }^{44}$ Jin's henchmen used that to threaten him and blackmail him into selling the orphanage to them. Distraught, Wei breaks down in tears, but Yin is determined that he and Wei will both appear in court to pursue the action, and Wei stays the night.

Early the next morning, the courtroom is already full of eager spectators waiting for the trial to begin, with the lawyers and reporters seated on the left side of the courtroom. Soon afterwards the five judicial officers - the chief judge, two associate judges, the prosecutor and the clerk - enter the court, all clad in black robes, and they take their places on the bench. When the defendant Jin enters the courtroom through a small door, all eyes turn to him, and the chief judge calls on the prosecutor to read out the charges. The judge then calls for the complainant (gaofaren) Yin Zhaoshi and the witness Wei Zhuoping, but their places are empty. The defendant smiles at Yin's absence as the judges consult the time; the session is scheduled for 10:00 a.m. and it is now 9:58. To the obvious disappointment of the crowded courtroom, the chief judge announces that the hearing will have to be postponed because the complainant and chief witness are absent, and he rises to leave the court.

Meanwhile, earlier that same morning we see Yin, his niece and Wei as they prepare to leave for court. Yin, now dressed in a suit and tie for this important occasion, pauses at the front gate to check for the gun they will take as evidence in the case. Jinxiu has it, along with the bullets, and Yin pockets it to take to the court. The coast seems clear and the three of them hurry down side streets-but several of Jin's henchmen suddenly materialize behind them, with more and more of Jin's thugs appearing at every turn. When Yin, Wei and Jinxiu manage to reach the main road, they are accosted by what is now a large group of threatening hoodlums, and a fight breaks out. It seems that Yin will never reach the court! But suddenly voices are heard on the street and a group of pedicab drivers, pedaling hard and fast, arrive to join in the fray. An anxious Wei and Jinxiu look on, but Yin himself is in the thick of the fighting.

\footnotetext{
${ }^{44}$ The baojia was a traditional collective neighborhood organization system intended to maintain order and control; it was used by the Nationalist Government and revived in Japanese-controlled areas. The head of each group was called a baozhang, but this was not an official position.
} 
Yin finally manages to extricate himself and the three of them break into a run to try to reach the court in time for the hearing. They arrive, fearing it is too late, but Yin calls out in a loud voice "Chief judge! It's Yin reporting," and he and Wei take their places in court in the nick of time. On hearing him, the judicial officials, on the point of leaving, return to the bench. Yin now addresses the courtroom as well as the bench: "I have many facts to prove all kinds of evil deeds committed by Mr. Jin and his henchmen. I want to accuse them! No, not I, but the many people who have been harmed now justly accuse them!" On hearing this speech, the defendant Jin, who had been confident of his escape, looks downcast and imagines the chains of imprisonment that await him.

At last the long trial is over and in the final court scene the judges' decision is at hand. There is a brief shot of bright sky and sunlight on green leaves, hinting at success in court-and a possible bright day. The five judicial officials return to the bench, and as the chief judge stands to read the decision, the audience in the packed courtroom is gripped with suspense; Wei, Jinxiu and even Mrs. Yin, who has for once left the kitchen behind, underscoring the importance of the occasion, all sit anxiously in the front row. As the chief judge announces the severe sentences they are handing down, Wei's relief is palpable. Jin is sentenced to life imprisonment and his property is to be confiscated; his henchmen receive long sentences for their crimes. In a civil action joined to the criminal case, the court has also declared that the orphanage property must be returned.

Lawyer Yin stands at the plaintiff's railing, gratified by the decision, while the defendants, now looking much the worse for wear, bow their heads, completely defeated by the efforts of a single brave lawyer. When reporters crowd around Yin for a statement as he leaves the courtroom, he replies, "I'm just happy!" But as he and Wei and Jinxiu make their way home after celebrating their great victory in court, Yin is viciously attacked by one of Jin's thugs and slumps to the ground. He has been seriously injured, and we next see him in bed surrounded by his anxious family and attended by Dr. Zhou. Can Yin recover from his injuries or is this the end? But as a ray of sunshine falls across the bed, Yin regains consciousness and smiles faintly, and his family are all relieved to see that he will be all right. 
D. "No, It's Not Far"

Cao Yu might have ended his film with Yin's courtroom victory, leaving us with the straightforward triumph of good over evil and a simple message of hope. The story might also have ended with the attack on Yin, or even his death: the forces of evil are too strong to be defeated, and the greatest sacrifice is demanded from those who dare to oppose them. Or perhaps simply with Yin's recovery and that ray of sunlight in his room: the dangers are very great but victory is still possible.

Instead there is one last sequence, and Bright Day ends on a high note, in stark contrast to the dark opening scenes of the film. In the final act, we see shots of bright sun on leaves and trees, and the sunlight reaches the Yins' house, where Yin, almost fully recovered, is sitting with Wei, Mrs. Yin and Jinxiu. Mrs. Yin bids her husband to rest and departs for the kitchen, but Yin slips out into the bright sunshine with Jinxiu, who has brought him another injustice to right. In the final sequence, we see Yin and his niece walk down a broad country road together. Yin is wearing his suit and tie and Jinxiu has on her special plaid cheongsam, the one she wore to court. Jinxiu slows her steps and then stops to ask her uncle, "Are we almost there?" Yin looks ahead, shielding his face against the sun. The sky is a brilliant blue, the road stretches far ahead of them, and there is sunlight everywhere. "It's not far," he replies, and together the two of them stride off into the future.

\section{YIN ZHAOSHI AS A LAWYER-HERO}

\section{A. A Traditional Official?}

In strong contrast to Cao Yu's plays, which tend to be short of heroes, Bright Day offers a definite hero in its protagonist, Lawyer Yin. Cao Yu certainly intended Yin Zhaoshi to be a hero, someone who tries to do good for others, especially those without power or money, who most need his help..$^{45}$ When discussing the subject of his film, Cao criticized the traditional Chinese viewpoint, reflected in the saying that you should "only sweep the snow from your own

${ }^{45}$ Da Wanbao [Shanghai Evening News], Apr. 4, 1948, in, CAO Yu Yanju Zhuanj 415 [Research Materials for Modern Chinese Literature, Cao Yu Research Collection]. 
front door but ignore the frost on other people's tiles." ${ }^{46}$ Yin Zhaoshi is therefore upright, honest and incorruptible, and his use of the law to seek justice is an important part of his identity. He is the kind of person who will not ignore injustice to others and instead actively involves himself on their behalf. Consequently Yin is a thorn in the side of the villains, who refer to him as the lawyer "who haunts us (yinhun busan)." ${ }^{47}$ Overall, Yin's character is intended to be a positive depiction of a lawyer, even if not all commentators viewed him in that light.

But Yin Zhaoshi is also a fully defined character, which owes much to Shi Hui's acting as well as to Cao Yu's script, and in many respects he is very Chinese. Other movie lawyers, notably in Long Live the Missus and Crows and Sparrows, to name two other 1940s films, wear Western suits and work from modern offices that are comfortable or even luxurious by the standards of the day. But Lawyer Yin cares nothing for appearances and very little for money. At home, Yin wears a baggy old Chinese jacket and trousers, and he never seems to comb his hair. It is only when he appears in court that we see him don a suit and tie, though even this outfit looks somewhat haphazard. Yin is down-to-earth and a man of the people, though perhaps he is a bit of an intellectual as well? He plays a traditional Chinese instrument, his study is full of books, and we see him wear glasses to read.

At forty, Yin may appear thin and weak, but he is actually very sturdy. When he throws a thug out of his house, he declares, "I beat a dog!" Yin has physical as well as moral courage, and he is not afraid to take on dangerous cases. He is beaten, then viciously attacked, and he must defend himself vigorously in the middle of a serious fight if he wants to reach the court. For contemporary audiences accustomed to realistic depictions of violence, Bright Day's fights are obviously faked, with the villains and Yin clearly pulling their punches. Yet the film succeeds in creating a genuine sense of menace and threat, and we understand just how ruthless Yin's opponents are. Nonetheless Yin faces them all bravely and, whatever the physical threats against him, he cannot be deterred.

\footnotetext{
${ }^{46} / d$.

${ }^{47}$ Literally, the ghost or spirit of a dead person has not departed, meaning something (unpleasant) lingers or an evil influence remains.
} 
Unlike other movie lawyers of that period, Yin Zhaoshi has no fancy suite of offices set in a skyscraper, high above the lives of ordinary people. Instead he works from home and sees at least some of his clients on the back step, where they can meet him on an almost equal footing. Yin is remarkably accessible, and can apparently be interrupted at any time (even while brushing his teeth) to speak with someone who needs his help. Yin seems to take most of his cases pro bono, such as an old lady who needs help with her landlord or an apprentice abused by his master, and looks for fee-paying clients only when his wife reminds him they are out of money or need wood for the fireplace. The Yins aren't exactly poor: they live in a large ground-floor apartment with its own yard, and indeed it looks much more comfortable than the screenplay suggests. But their place is sparely furnished and lacks the luxuries, such as heat, good lighting and a radio, that the villains so obviously enjoy. Even before their house is vandalized and its windows broken, the Yins are bundled up against the indoor chill and their breath is clearly visible in the cold. Mrs. Yin is also shown doing her own housework in virtually every one of her scenes, though professional families in other Chinese movies of the day all have servants to do it for them.

Yin Zhaoshi apparently values family and friendship, though he has almost no actual family in this film. The Yins have a companionable but very traditional relationship with each other; while he plays music as they sit together and chat, she continues knitting or darning-and she never joins him in his work. The Yins treat his niece Jinxiu like a daughter, and Wei and the orphans form a kind of extended family, as reflected in the polite forms of address they often use for each other. Bright Day is really a socio-political rather than a family drama and Yin's calling holds greater importance for him; with this limited and constructed family he can demonstrate his concern for the next generation without being distracted from his work. But this arrangement seems a bit hard on Mrs. Yin, whose interests have apparently been sacrificed for the sake of the plot. Although she is warm and motherly to all (in contrast to the rich woman she played in Long Live the Missus), in Bright Day she is given no children of her own; she seems to spend her days in household drudgery, and we never even learn her name. ${ }^{48}$ Yin places both

\footnotetext{
${ }^{48}$ In the screen credits as well as other lists of the cast, she is only "Mrs. Yin," and her character appears in none of the SHENBAO movie ads.
} 
his wife and niece in danger when he challenges the villains, and he presses "elder brother" Wei to testify despite the possibility Wei may be implicated as a collaborator if his wartime activities are revealed.

Lawyer Yin practices law on his own, but his niece Yin Jinxiu acts as a "partner" in his cases, or at least in his broader activities. It is Jinxiu who discovers what has happened to Wei and the orphans, who accompanies Yin to court, who writes about his appearance there, and who, in the final scenes of the movie, embarks on another adventure with him. Jinxiu's character provides a major role for the popular actress Li Lihua while giving Yin a much more glamorous partner than his wife, who dresses for housework and pulls her hair back in a knot. Jinxiu's presence also introduces a little (very low-key) romance to the story, when Jinxiu is courted by young Dr. Zhou-perhaps this allows the audience to imagine that the Yins will gain a son if Zhou and Jinxiu marry. ${ }^{49}$ But Jinxiu's activities, in which she is often accompanied by Zhou, may suggest the involvement of the younger generation in these important causes, for Yin, who turns forty in the course of the film, is viewed as well into middle age.

Whether they admired or disliked the character of Yin Zhaoshi, many commentators recognized his strong resemblance to traditional Chinese heroes. Thus Yin is adept at martial arts; when we first meet him, for example, Yin is practicing tai chi. " $[\mathrm{H}] \mathrm{e}$ is like some Chinese heroes of ancient times who are given to chivalrous conduct, or like men of integrity in traditional Chinese operas, such as the Four Examinees Successful in the Imperial Examination," all characters who exhibit bravery and dedication to justice. ${ }^{50}$ According to another critic, Yin is really a "warrior who is brave enough to firmly fight evil in a dark time ... but pure of heart like a baby, which reminds people of a Don Quixote. ${ }^{51}$ Or perhaps Yin is actually a kind of religious figure: "Yin belongs in the Buddhist Pure Land Heaven and not in court." 52 Viewed in this light, Yin is more like a traditional

${ }^{49}$ But if Jinxiu marries Zhou, will she too end up in the kitchen?

${ }^{50}$ CaO Yu Yanju Zhuanjo, supra note 46 , at 415.

51 Ding YePING, supra note 27, at 241-242.

52 ZHANG YAOJIE, supra note 31, at 279. This writer also criticizes Cao Yu's "inelegant way of letting viewers know that Yin and the Amitabha Buddha share the same birthday, as if the Buddha were his true self in a previous existence." Id. 
opera character or martial arts expert, or even a religious figure, than a modern lawyer-not surprising given Cao Yu's theater background and the Chinese audience he wished to reach.

\section{B. Or a Modern Chinese Lawyer?}

Some critics clearly admired Yin as a lawyer who loves to fight injustice, and in the story he seeks justice for his friend Wei and the orphans. Ignoring threats to his safety, he conducts a thorough investigation of the villains' activities; arguing in court with "fervor and assurance," he uses the law to make sure that the collaborator Jin gets the punishment that he deserves. Yin may be an ordinary man but he is honest, loyal and good, and his actions in this case definitely earn him the title "hero." 53

But is Cao Yu's creation also convincing as a modern lawyer? It's not just the lack of an office or the well-tailored suits of other Chinese movie lawyers. One commentator dismissed Yin as a "worker with some common sense about law." ${ }^{54}$ The judgment of another critic was even harsher: "Yin has no real knowledge of the law or doesn't use it. His weapon to help the poor and distressed is not the law but a kind of religious spirit. If an apprentice is mistreated, you should report it to the police, not a lawyer. And Yin behaves more like a policeman than a lawyer when he lectures the master on the way to treat his apprentices. In short, Yin resembles the martial arts expert who performs chivalrous actions, but these are not the actions of a modern lawyer." ${ }^{55}$ The worst example of Yin's failure as a lawyer is his handling of the sale of the orphanage or, more accurately, his failure to handle it, despite his professed affection for the children. Although Yin introduces himself as the "legal consultant for the orphans," he doesn't prevent the sale of the orphanage or protect their rights. When Yin later discovers the orphans' plight,

${ }^{53}$ Zhongguo Dianyingsh GangYaO, supra note 11, at 107. This 2007 discussion of Bright Day and Cao Yu's intentions in making it is a very sympathetic one. Cao $\mathrm{Yu}$ believed that "social justice can conquer evil, that the power of truth will achieve victory ... that people like Yin exist or will exist, he warmly depicted Yin's moral character and spirit of justice, which gave progressive people hope. Good will be rewarded with good and evil with be rewarded with evil is the truth that emerges in Bright Day."

${ }^{54}$ DING YePING, supra note 27, at 245-46

55 ZHANG YAOJIE, supra note 31 , at 279-80. 
he uses their tragic circumstances to bring a lawsuit that arouses popular emotions against Jin, really taking the government's role instead of directly helping the orphans. ${ }^{56}$ As a result, this author concludes, "regrettably, the Yin Zhaoshi that emerges from Cao Yu's pen has the façade of a lawyer but in his bones he has the consciousness of a completely upright official of traditional Chinese opera." ${ }^{57}$

We could certainly take the view that Lawyer Yang of Long Live the Missus is more accurately portrayed ${ }^{58}$ in the work that he does for his clients (marriage and divorce agreements as well as business advice), even though we never see him in court. Yang is easily recognizable as a lawyer to a contemporary viewer, and not just because of his office suite and Western suits. Lawyers help their clients in myriad ways, including advising and counseling, and they represent their interests out of court as well as before a judge, as Long Live the Missus shows. ${ }^{59}$ Yang counsels his clients and seeks to implement their truest wishes, even if that differs from their initial legal requests. Yang may be very different from Yin Zhaoshi, but he is one version of a model lawyer, the lawyer as friend, ${ }^{60}$ and many lawyers now would feel a greater professional affinity with him than with Yin.

Of course, if cinematic depictions of lawyers had to be completely true to life, few movies about them could ever be made. In the

${ }^{56} / d$., at 280. interesting criticisms of Yin's work as a lawyer (or possibly not a lawyer) than the purely political analyses. This critic also ridicules the movie's ending, in which Yin marches off in the sunlight in search of another injustice, having left his old wife behind. The reason Yin brings this kind of complaint, instead of a private civil action to recover the property, is discussed below.

${ }^{58}$ The screenplay for that film was written by one of China's most famous modern writers, Eileen Chang (Zhang Ailing), who knew something about lawyers and also divorce, the legal issue involved in the movie. I've written more about this movie in Don't Change Your Husband: Divorce in Early Chinese Movies, 40 CoNN. L. REv. 1245 (2008).

${ }^{59}$ In many of his scenes in Long Live the Missus, Yang is shown engaging in what to me looked like practicing law. But when I have shown slides of Yang advising his clients, nonlawyers in the audience often expressed disappointment, objecting that these were "not legal scenes."

${ }^{60}$ See Charles Fried, The Lawyer as Friend: The Moral Foundations of the LawyerClient Relation, 85 YALE L.J. 1060, 1067 (1976). 
1940s, lawyers were still relatively new in China, and what they did wasn't necessarily clear to critics any more than to playwrights, much less ordinary viewers. ${ }^{61}$ To be sure, Cao Yu's former wife, a Tsinghua University classmate, was a law graduate, and his older brother was a graduate of Peiyang University, which was renowned for its legal training. ${ }^{62}$ But Cao Yu studied drama in secondary school and he graduated from Tsinghua's Western literature department; ${ }^{63}$ he never studied law himself. In any event, Bright Day is not about a real lawyer, it's about Cao Yu's vision of what a lawyer-and ultimately justice-might be. Cao was entitled to that vision, and he didn't necessarily get it wrong.

\section{YIN'S DAY (OR POSSIBLY YEAR) IN COURT}

One aspect of Yin's work that surely marks him as a lawyer is his taking a case to court. Indeed, Bright Day is significant for its depiction of a trial as well as for the special role that Lawyer Yin plays in the proceedings. A few other pre-1949 movies contain courtroom scenes, but they are usually brief and serve to highlight the miserable plight of the accused or the vast distance between the judge and those he judges; only rarely do we catch a glimpse of a lawyer in court. ${ }^{64}$ Bright Day, however, offers the longest courtroom se-

${ }^{61}$ A modern, recognized legal profession was relatively new in China when Cao Yu was working on Bright Day. The Provisional Regulations on Lawyers (Lüshi Zhanxing Zhangcheng) were adopted on September 16, 1912. ZHENGFU GonGBAO [Government Gazette] vol. 5(1) 108 (1912). These regulations marked the first official recognition and definition of the legal profession, despite some earlier activity by "lawyers." For pre-1912, see Ng Hoi Kit, From Contempt of Pettifoggers to Willing Cooperation with Lawyers, CHINA Law 97 (June 2010). Shanghai had an active bar association and more lawyers than most other cities, but their numbers were still limited. By the end of 1936, the year before the outbreak of the Sino-Japanese War, Shanghai had 1,319 registered lawyers. SHANGHAISH NIANJIAN [Shanghai Annual] G167( 1936). In 1943, the Ministry of Justice statistics showed a total of 9,245 registered lawyers in China, fewer than in the late 1930s, though by then the country was at war. China HandBook 1937-44, 198 (Chinese Ministry of Information, 1944).

${ }^{62}$ ZHANG YAOJE, supra note 31, at 281. In the author's view, Cao Yu should have done better job depicting real legal activities for Yin.

${ }^{63}$ Bonnie S. McDougall and Kam LoUie, supra note 22 , at 177 . C.T. HSIA, supra note 23, at 318 .

${ }^{64}$ For example, in Song of the Fisherman (Yuguang Qu 1934), The Two-Mao Note (Liangmao Qian 1934) and even in Goddess (Shennü 1934), although the courtroom in the latter film is depicted realistically. Lawyer Fang in Street Angel (Malu 
quence in any of these early Chinese movies, and its trial scenes mark the high point of the film, with Lawyer Yin playing the starring role. The court case also generates the movie's suspense: will Yin and Wei make it safely to the court and can Yin win his case against such rich and powerful men?

Yin's role in court, which reflected actual procedure while echoing traditional courtroom drama, is of particular interest. Although Yin might be viewed as a kind of activist or people's lawyer in his other work, in his most important case he represents the prosecution, not the defense. Criminal procedure rules of the day permitted persons with information about a crime as well as those injured by it to initiate and pursue a criminal suit. ${ }^{65}$ In Bright Day, therefore, Yin investigates the facts of the case, interviews witnesses, prepares the complaint and then effectively prosecutes the case before a panel of judges and the prosecutor himself.

Indeed, Yin devotes all of his efforts to proving the case against Jin and his henchmen, in a trial that lasts throughout the year. Thus we see Yin emerge from his house during the heavy rains of spring, the worst of the summer heat, the strong winds of fall, and finally the deep cold of winter, on that occasion accompanied by his niece, with the two of them bundled up against the snow. "To the court!" he declares during all four seasons, and at night he dreams in restless sleep about this case. In his dreams, Yin pictures the three defendants walking slowly towards him in a dark swirl of mist, then imagines that, as a result of his efforts, the prison bars drop slowly down before them. "To the court!" he cries, as he sits bolt upright in bed, suddenly wakened from these fevered dreams. Should we take these scenes literally or do they merely suggest that the trial lasted a very long time? In Chinese court procedure of the day, as in many civil law systems now, judges did not sit in continuous sessions and trials could indeed be held over the course of a yearthough this still underscores how long and how hard Yin must work to succeed in this trial.

Tianshi 1937) does quote a price for a court appearance to a pair of would-be clients, but since they have no money to pay him we never see the courtroom. In its trial scene, Goddess includes only a brief shot of a lawyer defending his client in court (she is convicted).

${ }^{65}$ Ch'ien Tuan-Sheng (Qian Duansheng), The Government and Politics of China 256 (1950). 
Because Yin Zhaoshi has brought a very serious case, three judges rather than one preside over it, and both the prosecutor and the court clerk join them on the bench. ${ }^{66}$ All five judicial officials wear their prescribed dark robes, and the attendees rise as they enter to take their places in court, reflecting the importance of the occasion. The courtroom has an inquisitorial and not an adversarial layout, and the defendants stand together in the dock. Yin's position in this courtroom, as in the trial itself, is high: the plaintiff's box where he stands is raised nearly as high as the bench. From this vantage point Yin can survey the courtroom as he speaks, and almost every shot underscores his role in the trial. Cao Yu shows us that Yin is completely at home, this is his world, and we see the courtroom from Yin's perspective, not the perspective of a powerless defendant. ${ }^{67}$ Indeed, it is Yin's investigation and the documents he prepares, along with his eloquence in court, that prove the case, and not the presentation of any witnesses. The prosecutor does nothing more than read the charges ${ }^{68}$ and although Wei is the chief witness we never actually hear his testimony.

On my first viewing of Bright Day, I thought no defense lawyers appeared at the trial, though they certainly existed and these rich defendants could easily have paid their fees, but the screenplay states that the defense lawyers enter the courtroom and take their place in the court. The film itself does not record their entrance, but in the briefest of shots, a few seconds only, we see three lawyers sitting in their robes to the left of the prisoners' dock. If these

${ }^{66}$ The prosecutor continued to sit on the bench with the judge(s) until 1991, when in the Republic of China on Taiwan they were moved, over their strong objections, to sit below the bench; in 2005 prosecutors were again moved, this time to sit at the same level as the defense.

${ }^{67}$ As in the The Two-Mao Note or Song of the Fisherman. The latter film creates striking images of the distance separating officials from ordinary people. The contrast between the judge's position and that of the accused is the sharpest of any film, and we see it from their point of view (the judge looks enormous and towers over them) and from his (they are tiny figures before his authority). The court scenes in Bright Day create an entirely different feeling and give the viewer a very different message.

${ }^{68}$ Or perhaps he is reciting the prosecutor's "eight words": Ru qisushu yifa panjue (according to the indictment and in accordance with the law, decide the case), which he declared until the introduction in 2003 of reforms creating a more adversarial system in Taiwan. In any event, Bright Day shows us the prosecutor standing and reading, his only action in court. 
lawyers play any part in the proceedings, however, Cao Yu does not show it in his film: presumably Jin and his cronies are indefensible, and we should view them as such.

When thinking of heroic movie lawyers doing battle in court, many American viewers would automatically picture Atticus Finch in To Kill a Mockingbird, the 1962 film based on the 1960 novel by Harper Lee. Atticus too is upright and a believer in justice, and he takes action when others are afraid to do so; the dangers he faces and the threats of violence against him are all too real. But this comparison highlights what a very different role Cao Yu has Lawyer Yin play. In his trial, Yin effectively acts as the prosecutor, not the defense attorney who stands alone to defend his client against the power of the state, and Yin's opponents are very powerful but also clearly private thugs.

To Kill a Mockingbird can create suspense through the adversarial nature of the trial, even if its outcome can never really be in doubt. From this perspective, Cao Yu's filming of Yin's trial might seem a bit flat; for a common law viewer it lacks the drama of a battle between two opposing forces played out before an unpredictable jury. In Bright Day instead the suspense is whether Yin will succeed in getting to the trial to present his case, and whether he can present the evidence successfully to convince the judges of the defendants' guilt. Once Yin Zhaoshi arrives at the court, the show is his alone. The procedure is not adversarial, and even though the prosecutor and defense attorneys are present, we do not see them act; all attention is focused on Yin himself and the success or failure of his performance before the court. The defense lawyers do not rise to challenge Yin, and even the presence of a large courtroom audience only serves to emphasize the centrality of Yin's role in the trial, as well as the importance of the issues at stake.

In some respects, the trial in Bright Day also parallels traditional Chinese courtroom procedure, under which no lawyer could represent the accused, who always faced the judge-prosecutor alone. In his role in court as well as in his character, Yin is thus more like the upright and clever officials Judge Dee or Judge Bao than Atticus Finch; he is pursuing villains who have so far escaped punishment for their evil deeds, not arguing on behalf of a wrongly prosecuted innocent man. Indeed, there are strong parallels with traditional Chinese courtroom drama, in which righting an injustice by an hon- 
est official is a common theme, and the clever official seeks to uncover the crimes of the powerful and corrupt and to punish them for their crimes. Popular Yuan dynasty (1271-1368) drama (zaju), for instance, often featured courtroom stories, including those in which Judge Bao solves the case, and social justice was a major theme of this genre. ${ }^{69}$ Thus Lawyer Yin, in keeping with traditional Chinese ideas of justice, is willing to face and even prosecute the rich and powerful. And just as Yin's character might remind a Chinese audience of those upright officials, so his role at the trial, though cloaked in modern procedure, echoed themes of wellknown earlier plays. ${ }^{70}$

Overall, Bright Day presents a very positive depiction of a trialand indeed of the justice system as a whole. It is true that Lawyer Yin brings the complaint and he works hard to present the case, which would not have gone forward, much less have succeeded, without him. But the court is willing to accept and hear the case, the judges appear professional and impartial, and the trial is completely open to the press and the public. Even defense lawyers are present, though we do not see them act. In Bright Day, the law is used not to control and oppress ordinary people, but on the contrary it is turned against the rich and powerful. They are put on trial and-even more remarkably-they are convicted on the evidence.

Cao Yu's positive take on the process becomes even clearer when we compare Bright Day to Kunlun Film's Crows and Sparrows, with its biting critique of the pre-1949 justice system. ${ }^{71}$ In that film, a woman seeks the help of Lawyer Feng when her teacher husband is arrested and dragged away by the police. "Please help him," she

${ }^{69}$ Chung-Wen Shih, The Golden Age of Chinese Drama: Yüan TSA-chü 100-112 (1976). George A. Hayden, Crime and Punishment in Medieval Chinese Drama: Three Judge Pao Plays (1978). Ernst Wolff, Law Court Scenes in the Yüan Drama, 29 Monumenta Serica 193 (1970-71). Later plays, such as the Beijing opera Yutangchun, also contained dramatic trial scenes, and Chinese audiences were familiar with the conventions of courtroom drama. My thanks to Daniel Tschudi for this reference.

${ }^{70}$ Even Yin's dream about the trial has parallels in traditional plays: Judge Bao also dreams of his cases and the solution sometimes comes to him in a dream.

${ }^{71}$ As noted above, Crows and Sparrows was actually released after the 1949 revolution. In Crows and Sparrows, as in Stage Sisters, the law is used to harass people, not protect them-it isn't a shield, much less the sword it becomes in the hands of Yin Zhaoshi. 
pleads, as they sit together in his large office. "I'm sorry, but actually we don't dare handle cases like this," Feng tells her, and she begins to cry. Unlike Yin Zhaoshi, Lawyer Feng is scholarly in appearance, he seems genuinely sympathetic and he speaks with regret. But he does not take the case and the scene's message is clear: law provides no protection and no lawyer can save you. Even a braver lawyer than the effete Feng would have been powerless to act in such a system, and there is absolutely no question of going to court.

\section{ANALYSIS OF BRIGHT DAY: WHAT DOES IT ALL MEAN?}

\section{A. Yin Zhaoshi as a Victorious Lawyer (Who Acts Alone)}

The most interesting aspects of the film Bright Day, at least for the modern legal viewer, proved to be the most problematic politically: Cao Yu's characterization of a lawyer and his success in court. Even critics who acknowledged Bright Day's artistic merit expressed serious reservations about the plot, as well as the film's ultimate message. $^{72}$ The film opened barely a year before the Red Army entered Shanghai in May 1949, when the end of the civil war and the fall of the Nationalist Government were within sight. ${ }^{73}$ But in any event the Communist Party's views on the role of art and literature were already clear. According to Mao Zedong's 1942 Yan'an Talks on Literature and Art, (1) all art should reflect the life of the working class and consider them as an audience, and (2) art should serve politics, specifically the advancement of socialism. ${ }^{74}$ In late 1948 , the Party position on film was stated even more plainly: films should be allowed only if they were not harmful in propaganda but correct criticism should be organized. ${ }^{75}$

To be sure, one of Cao Yu's self-declared goals in making Bright Day was to depict the bleak atmosphere of crime, corruption and profiteering he encountered in postwar China. On his return to

\footnotetext{
${ }^{72}$ For example, in CAO Yu YANJIU ZIIIAO, supra note 39, at 265-66.

${ }^{73}$ Odd ARne WeStAD, supra note 10, at 221, 227, 250.

${ }^{74}$ This became the official Communist Party policy: art exists to serve the masses. MCDougall ANo Louie, supra note 22, at $193 \mathrm{ff}$.

${ }^{75}$ October 26, 1948 Central Committee instruction. OdD ARNE WESTAD, supra note 10 , at 252 .
} 
Shanghai in 1947, he said, he personally witnessed the widespread corruption and cheating, and he hated the society that produced it. ${ }^{76}$ Leftist commentators found much to like in this aspect of the movie, and they praised Cao Yu's depiction of the dark side of Chinese life and society after the war. "He indignantly reveals the sinister world of the areas returned to Nationalist control, in which traitors run amok and thugs do evil, the people are oppressed and good people have no way out." ${ }^{\prime 7}$ At the same time, such critics expressed regret that Cao Yu lacked the proper class perspective in his movie; perhaps Bright Day included "a socialist leaning and simple class concepts," but it failed to reflect a Marxist point of view. ${ }^{78}$ Even one of Cao Yu's former students declared himself dissatisfied with Bright Day because of Cao's "confused thinking" on political issues. $^{79}$

Even more objectionable, Cao Yu showed Yin's victory in court against his corrupt and powerful adversaries, and for that Cao was even more strongly criticized from the left. For the ideologically committed, the characters and ending of Bright Day could only be problematic, or at best completely irrelevant. Most difficult for them to accept was Yin's role as a lawyer and the way he used the court to bring about a just result. For example, film historian Cheng Jihua, writing in the early 1960s, treated Bright Day as one of Wenhua Film's "progressive" movies, and he praised its literary and artistic qualities. ${ }^{80}$ But according to Cheng the film also had some

${ }^{76}$ Tian BenXiang, Cao Yu Zhuan [Cao Yu Biography] 354 (1988).

77 Id., at 355-56, citing a XINMIN WANBAO [Xinmin Evening News] article from May 1948. In the same vein, Cao Yu "accurately reflects the bitter lives of people in areas returned to Nationalist control and exposes the traitors and thugs operating there." Qian Gurong, Cao Yu yu Tade Shuazuo [Cao Yu and His Printed Works], in CAO Yu ZhuANs (shang) [Cao Yu Special Collection] vol. 1, 158, 168 [Sichuan University Chinese Department, ed., 1979].

${ }^{78}$ Chen Soyun, CAo Yu Ju yu ZhengzhI [Cao Yu's Plays and Politics] 293 (Taipei 2007), quoting Chinese mainland sources.

${ }^{79} \mathrm{Cao}$ Yu had joined a revolutionary reading group with some of his students on his return to Shanghai in 1947. ZHANG YAOJIE, supra note 31, at 284-285 (2002). According to one source, after Cao Yu returned from the U.S. in 1947, his thinking underwent a major change, his contacts with the Communist Party increased and his belief that the Communists would win was strengthened. He thought China's only road was communism. Id. But Cao Yu didn't actually join the Party until 1956. TIAN BENXIANG, supra note 76, at 352.

${ }^{80}$ Zhongguo Dianying Fazhangshi, supra note 39, at 255-257. Cheng Jihua discusses some films made by the Wenhua studio, including Bright Day at 263-66. He lists 
serious flaws. Cao Yu's story departed from the social reality of the time, especially in making Yin victorious in his legal battle. Although Cao briefly touched on the support of the masses, for example, he made Yin's identity as a lawyer and the law more important factors in the result. In Cheng's view, however, the laws proclaimed by the "reactionary ruling class" could only serve to protect their rule; no one could rely on them, as Yin did, to obtain victory through individual struggle. ${ }^{81}$ "Actually, in real life at that time, upright people like the lawyer Yin Zhaoshi definitely could not have fought and defeated traitorous rich merchants like Jin."82 Cheng concluded that Cao Yu's thinking when he filmed Bright Day had not made much progress and remained at the general level of "capitalist democracy and humanitarianism."83

Others made similar criticisms: Cao Yu viewed "law" as most important, and believed that a lawsuit could succeed in sentencing bad people for their crimes. The main defect of Cao's story lay in making the struggle belong to the impassioned conduct of a single heroic individual who relies on law for his victory, when obviously law could not play such a role. "Yes, when all political power is held in the hands of the reactionary clique, how can you look to their law, can their courts issue just verdicts, can they truly eliminate the wicked forces and help the people?"84 Allowing an individual like Yin Zhaoshi to rely on a "fair and honorable court" in a capitalist dictatorship and defeat the rich Jin on his own might even influence people's view of the dark reality of that time. Bright Day might thus reflect "a socialist leaning and simple class concepts" but it definitely had not established a Marxist world view." ${ }^{85}$ Only the Communist Party could play the role of protector and savior.

For a process as well as a result much more to the tastes of such critics, we might consider the trial in a movie set at the same time as Bright Day but made after the 1949 Communist victory, Xie Jin's

all Wenhua films at $472-473$ but doesn't discuss the any of the "harmful" ones, including Long Live the Missus and Sorrows and Joys of Middle Age.

81 Id., at 265.

${ }^{82}$ Qian Gurong, supra note 77.

${ }^{83} / d$., at 168.

${ }^{84}$ TIAN BENXIANG, supra note 76, at 355-56.

${ }^{85}$ CHEN SOVUN, supra note 78, at 293. 
Stage Sisters (Wutai Jiemei 1964). ${ }^{86}$ Despite an almost identical courtroom setting, the trial itself plays out in a very different wayand in this court the law is used to persecute the innocent, not punish the guilty. No lawyers take an active part, though as in Bright Day we glimpse defense lawyers seated in the courtroom. The judges in Stage Sisters are clearly professionals, though it is not through any of their actions that the truth comes out. This trial is an open proceeding, and the court is packed with spectators, all deeply engaged in the drama before them. When the falsely accused defendant falls into a dead faint, the masses surge forward to support her, shouting "find the true criminal!" to the officials on the bench. Despite their best efforts to restore order to the court, the judges are helpless to continue the case. We thus see that justice will triumph when the masses stand up, and that the old corrupt order will be finished, swept away by the tide of revolution. The political message of this film, despite a nearly identical setting, is therefore entirely different from Cao Yu's in Bright Day.

More recent discussions of Bright Day are far less political and more sympathetic to its story, even if they still raise questions about its message. In a late 1990s discussion of Wenhua Film's "humanistic" movies, for example, Bright Day is viewed as the "ideal day" or perhaps "heaven." This reviewer recognizes that the main character is a lawyer, with a good disposition, a man who loves to fight injustice; he is not afraid of power and he works to redress an injustice to his friend Wei and the orphans, and although he is beaten, he ignores the threats and thoroughly investigates the facts. In court Yin argues with great assurance, revealing the true face of the villain; relying on the law, he causes him to receive the punishment he deserves. ${ }^{87}$ In this writer's view, Yin is one of those rare good people, a warrior who is brave enough to firmly fight evil in a dark time. "In any time or era, people like Yin must exist, and an idealistic, good soul who sacrifices himself for others, in the society of that time with good and evil hard to distinguish and true and false upended, is especially deserving of respect." But even this writer questions

\footnotetext{
${ }^{86}$ Xie Jin (1923-2008), one the most popular as well as acclaimed directors of the twentieth century. For the trial, see Alison W. Conner, Images of Justice (and Injustice): Trials in the Movies of Xie Jin, 35 Haw. L. Rev. 805 (2013).

${ }^{87}$ The discussion in this book suggests that the writer has actually seen the movie; at times it appears that some critics have not watched it.
} 
the possibility of Yin's victory through law. "The important point is, could one solitary good person succeed in that dark world? We can't deny that there are many individual good persons, without any firm political standpoint and with the pure heart of a baby like Yin Zhaoshi, who does battle with thieves and hooligans, who could possibly achieve another victory. But this kind of victory could only happen by chance, because actually Yin Zhaoshi couldn't have defeated them by himself." 88 Yin Zhaoshi's victory in court would certainly make the movie's audience happy. "But if viewers believed that good people could defeat such forces, wouldn't that give the evil forces an opportunity?"89

\section{B. Lawyer Yin as a Prosecutor of Hanjian}

One need not be an ideologue to question Yin's chances of success against those rich, and presumably politically-connected, defendants in court. By many accounts, judicial independence and due process of law remained unachieved goals under the Nationalist Government, ${ }^{90}$ even before China had suffered eight devastating years of war and invasion. Could Yin Zhaoshi really have won his case, even if Cao Yu makes it look risky and hard? In some respects it makes no difference: Bright Day is an expression of Cao Yu's ideas about law and justice, not a documentary film. ${ }^{91}$ But the answer is central to our understanding of the movie and its message(s), as well as the reasons that Cao Yu might have chosen a lawyer as his hero and sent him to court.

For the most part, Cao Yu's critics don't raise the issue, at least not directly, but Yin's trial is no ordinary trial and these are no ordinary defendants - they are actually collaborators or worse (hanjian). ${ }^{92}$ Although "collaborator" is a common English translation of

${ }^{88}$ DING YEPING, supra note 22, at 242-243.

${ }^{89} / d$., at 241-242.

${ }^{90}$ See, for example, Xu Xiaoqun, Trial of Modernity. Judicial Reform in Early TWENtieth-Century China, 1901-1937, 37 (2008); Ch'Ien Tuan-Sheng, supra note 65.

${ }^{91}$ We might also view it as a moral fable that isn't meant to be taken literally, just as we might view To Kill a Mockingbird as a moral fable. Realistically, Atticus Finch lost his case, but could he really have escaped any consequences for the role he played in the trial?

${ }^{92}$ Frederick Wakeman Jr., Hanjian (Traitorl) Collaboration and Retribution in Wartime Shanghai, in Becoming Chinese: Passages to Modernity and Beyond $298 \mathrm{ff}$. (Wen-hsin Yeh, ed. 2000). My discussion of hanjian and the hanjian trials relies 
hanjian, the term literally means "traitor" or "traitor to the Han people," a much stronger label that denoted the most serious crime against the nation. ${ }^{93}$ Even before the Nationalist Government had recovered Japanese-occupied territory, its leaders called on Chinese people to expose political and economic traitors and then launched trials against them. At least initially, the government encouraged individuals to bring accusations and even to write the complaints: "minor hanjian" cases could thus be brought to court by ordinary citizens. ${ }^{94}$

During the postwar hanjian-exposing years of $1945-47$ as well as during the Sino-Japanese War, some of those accused of collaboration were convicted and in a few cases even executed..$^{95}$ The trial of $\mathrm{Li} Z \mathrm{Z}$, the manager of the Sun Sun Company, for instance, presents a few parallels with the trial in Bright Day ${ }^{96}$ Like many other Chinese businessmen, Li Ze had remained in Shanghai and continued to operate the business during the Japanese occupation. After the war ended, Li was prosecuted for economic collaboration, following a popular campaign launched against him by Sun Sun clerks, who were underground members of the Communist Party. The clerks also formed a committee to collect evidence and bring legal proceedings against $L i$, and as a result of these and other activities, he was arrested in 1946. Li's trial, which lasted for more than half a year, was conducted in an intense political atmosphere, with lawyers on both sides engaged in pointed debates before a packed courtroom and the proceedings heavily reported in the news. At

on Margherita Zanasi, Globalizing Hanjian: The Suzhou Trials and the Post-World War II Discourse on Collaboration, AMERICAN HISTORICAL REVIEW (June 2008), 731-751; Yun Xia, "Traitors to the Chinese Race (Hanjian)": Political and Cultural Campaigns during the Sino-Japanese War of 1937-1945 (Ph.D. Dissertation, University of Oregon, September, 2010; WeN-HSIN YeH, SHANGHAI SPLENDOR 194-95 (2007).

${ }_{93}$ Yun Xia, supra note 92 , at $40-41$.

$94 / d .$, at iv-v., 98.

95 Id., at 103.

${ }^{96}$ Or the trial of Chen Gongbao in Suzhou in 1946, which was widely reported in SHENBAO. See Zanasi, supra note 92, at 731-51. Everyone opposed hanjian and called for their punishment, but leftists were particularly focused on economic hanjian-as Yin was in Bright Day. But Bright Day doesn't show the involvement of the masses, only the role of the lawyer; even though the court is full of spectators, they are quite passive, really just an audience for Yin Zhaoshi. In this respect, the case in Bright Day also differs from the real-life Sun Sun case, in which leftist agitation and activism triggered and supported the accusation and trial of Li Ze. 
the conclusion of the trial, Li Ze was sentenced to three years in prison and confiscation of his assets; ultimately his sentence was upheld on appeal, after further press conferences, popular appeals and labor actions. ${ }^{97}$ Yin's victory in court may therefore be a bit of a stretch (he was prosecuting very big fish), but it's not beyond the realm of possibility: if Yin could have brought and won any case in postwar Shanghai, it's this one.

This also suggests why Cao Yu might have chosen such a trial as the centerpiece of Bright Day: Cao returned to Shanghai in the middle of a vigorous patriotic campaign against traitors, and he wrote his screenplay and directed the movie at the height of anti-hanjian fever. During those immediate postwar years, newspapers carried intensive coverage of the trials of so-called economic collaborators (jingji hanjian), a label used to refer to anyone who had conducted financial activities with, or even under, the Japanese. ${ }^{98}$ Stories describing the luxurious lives led by hanjian who had gained their wealth by selling out their country were extremely popular during that period. ${ }^{99}$ That explains Cao Yu's depiction of the many luxuries enjoyed by the Bright Day villains, and the complete absence of any such comforts in the Yin household. Wealth was inevitably linked to corruption in the popular perception, as well as in the prosecutorial view, which took into account the economic status of the accused. ${ }^{100}$ It isn't just that Yin cares nothing about money or even

${ }^{97}$ WEN-HSIN YEH, supra note 92, at 191-196. For comparison with the sentences imposed in the Bright Day trial, see the charts of sentences given to major economic collaborators in Yun Xia, supra note 92, at 166-67. Yun Xia also provides a long analysis of the background to the Li Ze case, at 171-197. The discussion illustrates the problems inherent in this kind of trial-from everyone's point of view across the political spectrum. "Economic collaboration" was especially problematic. Most people who ran businesses during the Japanese occupation in practice had to collaborate in some fashion to operate in the occupied areas, and then risked being labeled as traitors and having their property confiscated when the war ended. See Parks M. Coble, Japan's New Order and the Shanghai Capitalists: Conflict and Collaboration, 1937-1945, in CHINESE COLLABORATION WITH JAPAN, 1932-1945, 135-155 (David P. Barrett and Larry N. Shyu, eds., 2001).

98 Yun Xia, supra note 92, at 143.

$99 / d$., at 291. A 1938 staging of Cao Yu's Sunrise by a banking association in Shanghai allowed the audience to understand that the powerful financier-villain was also a "collaborator" who sold out the Chinese. WEN-HSIN YEH, supra note 92, at $189-90$.

$100 / d$. , at 108. 
that he puts the interests of the people first, although both are true: more important, his lifestyle clearly signals to an audience familiar with these stories and news reports that Yin is not corrupt, indeed he is incorruptible. ${ }^{101}$

Viewed from today's perspective, the hanjian trials raise serious due process issues, even if Yin Zhaoshi's pursuit of the villains is depicted as a noble quest and the end result is just punishment for their crimes. But legal experts at that time also questioned the legitimacy and uncertain legality of the anti-hanjian laws as well as the way they were implemented. The 1945 hanjian regulations targeted a wide variety of people and groups, including people in very low-level organizations and positions. ${ }^{102}$ The possibility of false accusations, made mistakenly or out of spite, was very high, and some people believed that confiscation of property was the true goal of prosecution. Others argued that the trials compromised the authority of the judiciary, through corruption and political inference, ${ }^{103}$ and there seems little doubt that many such trials were conducted in an intensely political and patriotic atmosphere, hardly the setting to produce fair and considered judgments.

Cao Yu thus created a character with at least a double resonance for Chinese audiences of those hard postwar years. If Yin Zhaoshi reminds people of Judge Bao or famous opera heroes, then he is a character in a long tradition, and Cao's dramatic devices provided a useful shorthand for his viewers, who knew these conventions. But Yin is cast as a prosecutor for other, deeply political, reasons tied to the historical point at which Cao Yu was writing and directing Bright Day. Although prominent lawyers were actively engaged on both sides of the major hanjian trials, including the Sun Sun case discussed above, it would have been difficult politically (and perhaps emotionally?) for Cao Yu to make a defense lawyer the hero of his film. To be sure, there was a just side to those anti-collaborator trials, which offered redress for those who, like Wei and the orphans, had suffered because of the actions of wartime profiteers, and at

${ }^{101}$ This is a theme of other late-1940s films, especially those made by Kunlun Film, such as Spring River Flow East or $8000 \mathrm{~L} /$ of Clouds and Moon, for example.

102 Yun Xia, supra note 92, at 31-32, 47-50. This suggests that Director Wei was right to fear the consequences of his testimony for what it might reveal about his past; then he might also be accused and tried, along with the villains.

${ }^{103} / d$. , at 293. 
least some prosecutions brought genuine wrongdoers to justice. But could a lawyer like Yin have withstood the emotional and political tide of leftist as well as government campaigns against "economic collaborators"? ${ }^{104}$ In the movies, perhaps only Atticus Finch could have done it, and not without paying a price.

\section{When Is the Bright Day?}

Bright Day and its message can certainly be read in varying ways. Like some other movies of the late 1940s, the film paints a bleak social and political picture, at least at first. From its ominous opening scene, Cao Yu creates a strong feeling of menace, and he shows us the powerful, ruthless forces at work against justice and law. But the film closes on a positive, even uplifting, note. Although the forces of evil are powerful, and the dangers very great, an individual who believes in justice and is willing to fight for it can still defeat them, and perhaps achieve more.

Of course, Bright Day doesn't end with Yin's victory in court, or even his recovery from the villains' vicious attack, as we see that ray of sunlight enter his room. Instead there is one final sequence, set in brilliant sunshine on an open country road. Where are Yin Zhaoshi and his niece going, as they stride off together in the film's closing scenes? Perhaps Cao Yu was suggesting that the bright day had not quite arrived, that this was an ideal not yet attained; Yin and Jinxiu (and all Chinese) would find their bright day only in a better future. Other movies filmed during the postwar years that paint even darker pictures of society end on a similarly hopeful note, and like the characters in all of these movies, we too sense that a better day is coming soon. ${ }^{105}$

${ }^{104}$ Li Ze did in fact have legal representation, including Sun Sun company counsel Zhang Shizhao and Chen Tingrui. There were also distinguished, well-known lawyers advising the defendant and the Sun Sun clerks. WEN-HSIN YEH, supra note 92, at 194-95. But Chen Tingrui (D.S. Chen), who was American-trained and a leader of the Shanghai bar, was a very different sort of lawyer from Yin Zhaoshiand he later left for Taiwan.

${ }^{105}$ Such as The Watch (Biao, Wenhua Film Company 1949) or The Lights of 10,000 Homes (Wanjia Denghuo, Kunlun Film Company 1948). Filming of The Watch began in early 1949, but it was finished after the Communists came to power later that year. LEYDA, supra note 42, at 174. In Crows and Sparrows, which was not released until after October 1949, that better day actually arrives. 
Yin Zhaoshi may play a prosecutorial role, but Cao Yu has still made an upright lawyer the hero of his film, a highly questionable choice from the perspective of his left-wing critics. Cao Yu may have known more about theater than he did about law, but he had some legal connections and in 1947 he had just returned from the United States, where law was highly regarded and often discussed. As Cao later wrote, "at that time I viewed law as the fairest way, even though I knew the Nationalist law wasn't all that just." 106 According to Cao Yu, after the Communist victory in 1949, he was told he should change the movie: "only a few scenes needed to be redone and then it would be all right." But Cao was engaged in other projects and he thought the film was "just something made at that time, it expressed one viewpoint, and I didn't want to change it." ${ }^{107}$ Consequently Cao Yu never made the changes and Bright Day remains as he filmed it. ${ }^{108}$

Cao Yu's critics weren't wrong when they said he made legal justice the ideal, when they took that as the movie's (unreconstructed and unrevised) message, or when they understood the heroic role Cao gave Lawyer Yin. When Cao Yu was criticized for emphasizing the power of individual action, he replied that Yin and his niece were going to Yan'an. ${ }^{109}$ But in those last scenes Yin and Jinxiu are wearing their armor-the suit and the plaid cheongsam they wore to the trial-as if they were once more headed off to do battle in court. ${ }^{110}$ Whenever that bright day begins, Yin's trial is depicted in a positive light: even the rich and powerful can be defeated in court

\footnotetext{
106 TIAN BENXIANG, supra note 76, at 356.

${ }^{107} / d$.

${ }^{108}$ Cao Yu's plays, which were written well before he joined the leftist movement or the Party, had also been criticized for political reasons, and they were revised and given different readings from their earliest performances. Early productions fashioned an ideological reading of Thunderstorm, for example, by deleting the epilogue and prologue, and after 1949 even Cao accepted that reading. Xiaomei Chen, supra note 2 , at 12-13. Basically, the criticism was that Cao's plays were irrelevant to a theater for workers and peasants. Gunn, supra note 23, at 41-42. Of course plays-unlike films - can easily be edited, reworked or abridged for every performance in order to suit the prevailing political taste.

${ }^{109}$ Yan'an in Shaanxi province was the wartime capital of the Communist Party from 1936 to 1948, when Bright Day was being filmed.

${ }^{110}$ Or perhaps Cao was suggesting that you can win temporary victories now, but the final triumph will only come with the revolution?
} 
and receive the punishment they deserve. ${ }^{111}$ The revolution may be coming, but Yin is hardly a revolutionary. He believes in the law and he seeks justice in court - and his faith in the legal process is vindicated by the result.

\section{CONCLUSION}

\section{A. Bright Day as a Film}

How should we assess Bright Day as a film? Wenhua Film made some of the best Chinese movies of the 1940s and its sophisticated comedy-dramas, such as Phony Phoenixes, Long Live the Missus, and Sorrows and Joys of Middle Age, hold up well for contemporary viewers. Despite a few Chinese features (the presence of "concubines" or the absence of filial piety, for example), the "universal" themes of these films would be accessible to anyone who has ever seen a Hollywood movie. Even Kunlun Film's epics, so firmly rooted in a particular place and time-the Sino-Japanese War and its aftermath-offer historical sweep and powerful drama that can speak to audiences today.

Bright Day is a very good film in many respects, even if it doesn't reach the heights of Wenhua's best. ${ }^{112}$ Not surprisingly, given its screenwriter-director, Bright Day often feels like a filmed play rather than a movie; Cao Yu shot mainly interior scenes, and the characters, especially Yin Zhaoshi and his niece, are given speeches that would work well on the stage. Yet the film does contain some very effective exterior scenes, including an opening sequence that creates a genuine sense of foreboding as the movie begins. In Bright Day, Cao Yu also used action sequences to highlight the dangers its main characters faced in pursuing their case, and he succeeded in heightening the suspense as Yin and Jinxiu try to reach the court. Cao Yu's choice of music, from Sibelius to Mozart, intensified the

111 If this was possible, then surely the bright day had already arrived-but Cao Yu was familiar with the Nationalist justice system and this was probably not his belief (nor the way many in his audience saw it).

${ }_{112}$ It's hard to watch Bright Day alongside Sang Hu's Long Live the Missus or The Sorrows and Joys of Middle Age without concluding - at least at this remove in time from the events (and emotions) that Cao Yu depicts-that Sang Hu was a better movie director than Cao Yu. 
mood of these scenes, and Bright Day showcased the talents of China's great stage and theater artists of the day.

However good a movie Bright Day may be, its themes seem less accessible now, especially to a non-Chinese audience, than those of many other Wenhua films. Cao Yu was very much focused on the concerns of his own time, including corruption, inequality, the punishment of "traitors" and a general feeling of oppressive, malevolent forces at work. He also drew heavily on Chinese theater conventions and traditional heroes like Judge Bao to shape the character of his lawyer-hero Yin Zhaoshi. But Bright Day is capable of a much broader reading, as Cao Yu shows us the ability of an individual to act against corrupt powers, and the role of the courts (and yes, a lawyer) in redressing injustice. What could be more timely, or more universal, than that? ${ }^{113}$

To be sure, Yin isn't a flesh-and-blood lawyer, he's a creation of Cao Yu, and the actor Shi Hui. But l've thought about what kind of lawyer Yin Zhaoshi might be, and whether there might be parallels with Chinese lawyers-or ideas of Chinese lawyers-today. In some respects, through his friendship with and advice to members of the "masses," Yin resembles the 1950s "people's lawyers," who were popular before the Communist Party turned its back on legal reform. ${ }^{114}$ But Yin might also remind us of China's activist lawyers now, even if he isn't precisely a "rights defender" (weiquan) in his work. ${ }^{115}$ Lawyer Yin doesn't strive to defend people's rights under the law in the same way that current activists do, and he certainly doesn't try to defend anyone against a criminal charge. On the contrary, Yin uses the law as a sword not a shield, ${ }^{116}$ and he uses it to prose-

${ }^{113}$ To Kill a Mockingbird, although set in the 1930s South, was released during the civil rights movement of the 1960s, and it resonated strongly with people working towards racial justice in a violent and dangerous time. Some fifty years later, the film may seem less immediate as well as somewhat old-fashioned, and of course it was filmed in black and white. But Atticus Finch still embodies the lawyerideal for many-and has racial justice in the U.S. been achieved?

${ }^{114}$ See Shao-Chuan Leng, Justice in Communist China 134-43 (1967).

115 On the rights defender lawyers, see, for example, Stacy Mosher and Patrick Poon, A Sword and a Shield: China's Human Rights Lawyers. (Stacy Mosher and Patrick Poon, eds., 2009); Eva Pils, "Disappearing" China's Human Rights Lawyers, in Comparative Perspectives on Criminal Justice in China (Mike McConville and Eva Pils, eds., 2013).

${ }^{116}$ It can be difficult now in China to use the law as a shield, much less as a sword. In 2011, for instance, a Chinese foreign ministry spokeswoman told foreign 
cute the defendants in court, where he plays a more important role than the judges themselves. His adversaries are private interests, and he doesn't directly challenge the power of the state, as rights defenders often do, when they try to use the courts and the media for their causes. Indeed, the state allows him to bring his case, the court hears his case impartially in an open trial, ${ }^{117}$ and he pays no (official) price for his actions.

Nowadays activist lawyers face harassment and persecution from the Party-State, a more formidable adversary than anything Cao $\mathrm{Yu}$ could have imagined in the late 1940s. In Bright Day, it is private thugs who threaten and beat Yin, but now it is thugs employed, at least indirectly, by the authorities themselves. Against the PartyState, in contrast to the defendants in Bright Day, no recourse can be had from the courts; even winning against powerful local interests seems out of the question. News reports and videos widely available on the internet make the movie's violence look very tame indeed: now rights defender lawyers are not only beaten, but detained, imprisoned and disappeared. ${ }^{118}$

\section{B. Bright Day's Message Then and Now}

Yin Zhaoshi is a lawyer-activist, ${ }^{119}$ but very much of his time, in a dark period when victory seemed like defeat. He acts as the prose-

journalists who had been beaten up by Chinese police while going about their work: "Don't use the law as a shield." Some people, she said, want to make trouble in China and "for people with these kinds of motives, I think no law can protect them." Quoted in THE ECONOMIST, April 4, 2011, "A Spear not a Shield."

${ }^{117}$ The contrast with current high-profile trials in China (of fallen Party leader Bo Xilai, for instance) could hardly be greater: even Cao Yu's plays were less scripted and staged, and at least in the film there was some doubt about the trial's result.

${ }^{118}$ Amnesty International, Against the Law: Crackdown on China's Human Rights Lawyers Deepens (2011, available at http://www.amnesty.org/en/library/info/ ASA17/018/2011/en; Human Rights in China, Xu Zhiyong, Advocate of Disclosure of Official Assets, Criminally Detained, available at http://www.hrichina.org/ content $/ 6822$. The list of news reports even for the last two years, since 2011, is depressingly long.

119 In earlier discussions of Yin Zhaoshi-written before I was able to see the movie-l've thought of him as a revolutionary (definitely wrong) or a rights defender (close but not exactly); in fact he is an honest lawyer struggling with the issues of his time. Chinese Lawyers on the Silver Screen, in CINEMA, LAW, AND THE STATE IN AsIA (Mark Sidel and Corey Creekmur, eds., 2007); Bench and Bar: Lawyers and Judges in Early Chinese Movies, 39 H.K.L.J. 575 (2009), and Movie Justice: The Legal 
cutor in his biggest case, a role well suited to Chinese taste and traditions as well as to the postwar mood. Indeed, Yin seems more Chinese than many other movie lawyers: he wears Chinese clothes at home, practices tai chi and relaxes by playing a traditional musical instrument. He is nothing like the westernized and well-tailored lawyers of Shanghai's foreign concessions, whom we meet in Long Live the Missus and Crows and Sparrows or other early Chinese films.

Cao Yu's contemporaries certainly recognized that Yin is a lawyer who fights against injustice on behalf of the oppressed, ${ }^{120}$ and like many Chinese lawyers today, Yin believes in justice and relies on the law. He champions the powerless and is unafraid to denounce evildoers, however rich and powerful they may be. Despite warnings and serious threats to his life, Yin perseveres to make the case against the wrongdoers in court, and it is through his brave efforts that they are finally brought to justice. Even after Yin has been viciously attacked, his spirit remains undaunted. According to a contemporary critic, Cao Yu "firmly believed that justice is bound to triumph. Because of this belief, the just characters struggle with the evil and try to open the way to a new future. When we hold the truth, we cannot be subdued by force."121 Upon seeing the film, the president of the Shanghai Drama Institute declared, "Let's pray that outside the screen, too, a bright day will come to the Chinese people." ${ }^{122}$

China has real, not just cinematic, lawyer-heroes now, but Cao Yu's story remains relevant, and it raises hard questions still pressing today. What role can and should lawyers play in the Chinese justice system, and what risks or dangers do they face? And when will that bright day, with lawyers free to act and justice accessible to all, arrive? Unfortunately, if present events in China are any indication, it seems that day, along with Bright Day's vision of justice, remains as distant as ever.

System in Pre-1949 Chinese Film, 12 A.P.L.P.J. 1 (2010). But there are at least some parallels with activist lawyers in China today.

${ }^{120}$ ERSHI SHIJ ZHONGgUo WeNYI TUWENZHI, supra note 15, at 83.

${ }^{121} \mathrm{Hu}$, supra note 7, at 174. Cao believed in the importance of law, even if the law of his day was not completely just. Chen Jingliang and Zou Jianwen, eds., BAINIAN Zhongguo Dianying JingXuan (The Best of Centennial Chinese Cinema) 1905-2005, vol. 1270 (2005).

${ }^{122} \mathrm{Hu}$, supra note 7 , at 174 . 